\title{
PENGAMBILAN KEPUTUSAN TERHADAP TINGKAT PENGETAHUAN PERAWAT DALAM KEPERAWATAN KLINIS TRIASE DI RUANG IGD
}

\section{SELLY FEBI MARGARETHA PANGGABEAN}

\author{
sellyfebi2601@gmail.com
}

\section{LATAR BELAKANG}

Instalasi gawat darurat merupakan salah satu uni di rumah sakit yang umumnya harus dapat memberikan pelayanan kegawatdaruratan secara umum baik bersifat akut, kronis, korban kecelakaan, dan berbagai pelayanan kegawatan lainnya yang memerlukan penanganan dengan segera. Triase adalah suatu proses penggolongan pasien berdasarkan type dan tingkat kegawatan kondisinya. Triase juga diartikan sebagai suatu tindakan pengelompokkan penderita berdasarkan pada beratnya cedera yang diprioritaskan ada tidaknya gangguan pada airway (A), breathing (B), dan Circulation (C). Tujuan ialah untuk meningkatkan pengetahuan perawat dalam pengambilan keputusan saat pelaksanaan triase, agar seorang perawat tidak salah dalam mengambil tindakan yang akan dilakukan di ruang Instalasi Gawat Darurat (IGD).

Sistem triase merupakan salah satu penerapan sistem manajemen risiko di Instalasi Gawat Darurat (IGD) sehingga pasien yang datang mendapatkan penanganan dengan cepat dan tepat sesuai kebutuhannya dengan menggunakan sumber daya yang tersedia. Triase adalah aspek penting dalam merawat pasien di ruang IGD berupa penilaian awal yang dilakukan selama pasien masuk ke IGD. Triase adalah langkah yang paling penting dalam ruangan gawat darurat. Tujuan utama dari triase adalah untuk menurunkan angka kesakitan dan kematian bagi seluruh pasien yang masuk ke IGD (Garbez et al,2011). Triase rumah sakit (hospital triage) atau populer disebut triase gawat darurat. Triase terdiri dari triase primer dan sekunder. Triase primer terkait dengan prosedur penilaian primer dan alokasi pasien terhadap pengobatan. Triase sekunder terkait dengan inisiasi intervensi keperawatan dan memberikan kenyamanan kepada pasien. Pengetahuan, sikap dan keterampilan perawat sangat dibutuhkan dalam pengambilan keputusan 
klinis agar tidak terjadi kesalahan dalam melakukan pemilahan saat triase sehingga dalam penanganan pasien bisa lebih optimal dan terarah (Oman 2008). Penilaian triase yang tidak sesuai dengan keadaan pasien memiliki resiko dalam meningkatkan angka kesakitan, mempengaruhi hasil perawatan pasien, atau kriteria hasil yang akan ditetapkan untuk perawatan pasien.

Pengambilan keputusan klinis mengenai triase berdasarkan kategori prioritas pasien menentukan tatalaksana asuhan keperawatan gawat darurat yang akan diterima oleh pasien. Peran triase membutuhkan keterampilan penilaian klinis yang sangat tinggi, dan dasar pengetahuan yang relevan untuk membedakan keluhan yang tidak mendesak dari kondisi yang mengancam jiwa dilingkungan pekerjaan sibuk dan membuat stres (Varndell et al, 2019). Untuk memprioritaskan pasien, pedoman triase harus direncanakan, dibuat sesuai konsep, yang terdiri dari interpretasi riwayat klinis dan informasi klinis, alokasi pasien sesuai kode urgensi, dan disposisi ke area perawatan yang sesuai dalam IGD. Faktor informasi klinis mencakup keluhan utama pasien pada saat datang ke IGD, tanda - tanda vital pasien, tanda dan gejala yang menyertai, dan riwayat kesehatan pasien (Garbez et al., 2011). Perawat yang berdinas di ruang IGD adalah perawat yang memiliki sertifikasi sebagai perawat gawat darurat dan memiliki pengalaman kerja yang baik di IGD. Saat ini, di Indonesia masih sangat kurang diketahui model perawatan triase, persiapan dan pendidikan mengenai triase di Rumah sakit, dan proses penjaminan triase. Di beberapa rumah sakit di Indonesia, penilaian triase dilakukan oleh perawat yang telah memiliki pelatihan gawat darurat, dan pelatihan triase. Ketepatan penilaian triase dan capaian keselamatan pasien merupakan salah satu implikasi dari penilaian triase. Pelatihan triase, pengalaman bekerja di ruang emergensi, dan keterampilan triase merupakan faktor - faktor yang dapat mempengaruhi pengambilan keputusan klinis triase (Varndell et al., 2019). Pengambilan keputusan keperawatan dilakukan pada semua tahap proses keperawatan. Sehingga seorang perawat harus mampu berpikir kritis, berkomunikasi dengan baik sebagai suatu elemen penting dalam pengambilan keputusan klinis, sehingga terjadi pembelajaran berkelanjutan bagi pasien sehingga meningkatkan tingkat kemandirian pasien serta perlu dipahami bagi perawat juga bahwa pengambilan keputusan klinis dengan melibatkan klien akan erat hubungannya dengan nilai - nilai budaya yang dianut oleh klien. 


\section{METODE}

Dalam kajian ini, metode yang digunakan oleh penulis adalah kajian bebas (literature review), dengan cara membaca, menganalisis, menyimpulkan kajian jurnal online, textbook, ebook, serta buku pedoman yang terkait dengan pokok bahasan dari kajian yakni pengambilan keputusan terhadap tingkat pengetahuan perawat dalam keperawatan klinis triase di ruang IGD. Dengan menggunakan jurnal dan referensi yang digunakan pada kajian bebas (literature review) ini dengan tahun terbit paling lama 2012, dengan jumlah minimal 10 referensi.

\section{HASIL}

Berdasarkan hasil analisis dari pencarian beberapa sumber literature review, didapati beberapa faktor yang sangat mempengaruhi pengambilan keputusan terhadap tingkat pengetahuan perawat dalam keperawatan klinis triase di ruang IGD. Adapun hasil dari beberapa jurnal terkait kajian diatas yaitu :

Dalam Jurnal Pertama, Faktor - Faktor Yang Berhubungan Dengan Pengambilan Keputusan Perawat Dalam Ketepatan Triase Di Kota Padang Vol.02,No.01, 2018. Menurut hasil analisis jurnal tersebut, bahwa faktor dominan yang berhubungan dengan pengambilan keputusan perawat pelaksana terhadap ketepatan pengisian skala triase, dapat disimpulkan bahwa variabel yang diduga memiliki hubungan paling kuat dengan ketepatan pengisian skala triase adalah variabel tingkat pengetahuan dengan $p$ value 0,012. Sedangkan pada variabel lama bekerja 17,856 yang artinya adalah tingkat pengetahuan mempunyai peluang yang menyebabkan ketidaktepatan pengisian skala triase. Oleh karena itu, lama bekerja mempunyai hubungan positif dengan ketepatan pengisian skala triase.

Dalam Jurnal Kedua, Pengetahuan Dan Keterampilan Perawat Dalam Pengambilan Keputusan Klinis Triase 16 (1), 2020. Menurut hasil analisis jurnal tersebut, bahwa ketepatan triase, dapat disimpulkan dari data - data responden, bahwa lebih dari separuh $(65,9 \%)$ perawat menilai triase dengan klasifikasi under triage, dan kurang dari separuh $(34,1 \%)$ perawat yang menilai triase dengan klasifikasi over triage. Dan 10 dari 54 atau sekitaran $(18,5 \%)$ perawat dapat menilai ketepatan triase dengan tepat. 
Maka dari hasil perbandingan jurnal - jurnal tersebut, dapat disimpulkan bahwa pengambilan keputusan terhadap tingkat pengetahuan perawat dalam keperawatan klinis triase di ruang IGD sangat mempengaruhi tingkat pengetahuan, ketepatan dalam pengisian triase serta lama bekerja seorang perawat dapat juga dinilai dalam mempengaruhi keputusan akhir yakni dalam peningkatan angka keselamatan pasien, meningkatnya kualitas dari layanan kesehatan dan menjamin mutu pelaksanaan triase serta mendukung implementasi dari keselamatan pasien diruang gawat darurat.

\section{PEMBAHASAN}

Triase merupakan salah satu bentuk dari proses pengambilan keputusan klinis, yang terdiri dari proses penilaian, dan memberikan prioritas kepada pasien berdasarkan kondisi klinis (Dadashzadeh, et all., 2014). Kondisi yang tidak jelas, dan keterbatasan informasi sering menjadi hambatan yang dialami perawat dan tim triase lainnya dalam menentukan skala prioritas dan tindakan penyelamatan yang diberikan selanjutnya. Pengetahuan perawat merupakan salah satu faktor yang dapat mempengaruhi kinerja seseorang. Hal ini tersebut juga terjadi pada penilaian triase. Pengetahuan menjadi daya dorong utama individu untuk melakukan berbagai aktifitas dalam kehidupan, dari adanya pengetahuan yang baik dapat memacu dan meningkatkan kepercayaan diri untuk bekerja sehingga mendapatkan hasil yang baik pula.

Pengetahuan perawat di IGD diperoleh dari beberapa aspek seperti pendidikan, umur, dan jenis kelamin. Dimulai dari aspek pendidikan, Menurut Notoatmodjo (2010), mengatakan bahwa tingkat pendidikan seseorang akan memengaruhi pengetahuannya. Petugas kesehatan IGD yang dapat melakukan tindakan triase minimal berpendidikan D3 keperawatan. Semakin tinggi pendidikan seseorang maka, semakin mudah pula mereka menerima informasi dan makin banyak pula pengetahuan yang dimilikinya. Lulusan diploma 3 memiliki kemampuan yang cukup untuk dapat melakukan pengambilan keputusan dalam menentukan hasil triase pasien di ruang IGD (Gurning, Karim \& Misrawati, 2014). Selain didasari dengan aspek pendidikan, aspek umur juga memengaruhi pengetahuan perawat dalam melakukan tindakan keperawatan, terutama dalam tindakan triase. Berdasarkan dengan aspek atau karateristik faktor umur, untuk usia atau umur $\geq$ 30 tahun merupakan usia yang lebih matang dalam dunia kerja keperawatan dalam melakukan tindakan triase, bahwa usia akan mempengaruhi jiwa seseorang yang menerima untuk mengolah kembali pengertian - pengertian atau tanggapan, sehingga dapat dilihat bahwa semakin tinggi 
usia seseorang, maka proses pemikirannya untuk bekerja melakukan tindakan di Rumah sakit lebih matang atau lebih siap. Semakin bertambahnya usia, maka daya tangkap dan pola pikir seseorang semakin berkembang. Usia yang cukup terhadap tingkat kematangan dan kekuatan seseorang akan lebih matang dalam berpikir dan bekerja. Selanjutnya pada aspek atau jenis kelamin, berdasarkan karateristik faktor jenis kelamin juga menentukan tindakan dalam melakukan triase. Menurut Fathoni (2014), menyatakan bahwa petugas kesehatan IGD berjenis kelamin laki - laki secara fisik lebih kuat dibandingkan perempuan tetapi dalam hal ketanggapan memilah pasien tidak ada perbedaan dengan petugas kesehatan yang berjenis kelamin perempuan. Sebagai contohnya adalah perbedaan perilaku antara pria dan wanita dapat dilihat dari cara berpakaian atau cara melakukan pekerjaannya sehari - hari. Pengetahuan tentang triase yang dimiliki oleh petugas kesehatan IGD akan sangat membantu petugas dalam mengenal kasus - kasus kegawatan dan selain itu berguna juga untuk kualitas pelayanan dan juga dapat mencegah kematian dan kecacatan lebih lanjut (Gurning, 2012). Pengetahuan merupakan aspek penting yang harus dimiliki seorang petugas karena dapat memengaruhi keterampilan tentang triase. Pengetahuan yang tinggi, seseorang akan mampu melaksanakan semua tugas secara efektif dan efisien, sehingga kinerja semakin membaik. Menurut Setyo uji (2015) pengetahuan atau kognitif merupakan domain yang sangat penting untuk terbentuknya suatu tindakan. Perilaku yang didasari pengetahuan akan lebih langgeng dari pada yang tidak didasari dengan pengetahuan. Semakin rendah pengetahuan seseorang tentang triase, maka tindakan terhadap triase berdasarkan prioritas juga tidak akan sesuai.

Kesalahan dalam penilaian triase menurut ketepatannya dapat digolongkan menjadi dua yakni undertriage dan overtriage. Undertriage adalah penempatan triase yang tidak memadai (dibawah tingkatan kegawatan yang seharusnya), sehingga meningkatkan resiko penurunan status kegawatan pasien selama menunggu (Grossman,2014). Overtriage adalah kesalahan triase dimana pasien yang seharusnya tingkat kegawatannya rendah dianggap tingkat kegawatannya tinggi. Dalam menilai prioritas triase, diperlukan indikator penilaian yang terstandar. Adapun poin - poin penilaian triase dapat dijabarkan sebagai berikut (Rahardjo et A1,2009) : 


\section{Primary Survey}

Merupakan proses deteksi cepat dan koreksi segera terhadap kondisi fungsi organ vital yang terancam. Primary Survey dilakukan dengan mengecek kesadaran korban dilanjutkan dengan memeriksa fungsi vital dengan sistematika $\mathrm{A}, \mathrm{B}, \leq \mathrm{C}$ secara cepat.

2. Secondary Survey (Head to Toe)

Didefinisikan sebagai proses pencarian perubahan - perubahan fisik anatomis yang dapat berkembang menjadi lebih gawat dan dapat mengancam jiwa apabila tidak segera diatasi. Secondary Survey dilakukan setelah survey primer tuntas.

3. Pemantauan korban / pasien akan kemungkinan terjadinya perubahan - perubahan kondisi :

a. Fungsi jalan nafas, fungsi pernafasan dan fungsi sirkulasi

b. Derajat kesadaran

c. Tanda - tanda vital yang lain

4. Perubahan prioritas yang dikarenakan berubahnya kondisi korban / pasien

Tindakan yang harus dilakukan perawat dalam proses pengambilan keputusan triase adalah sebelum menentukan triase perawat IGD harus melakukan pengumpulan data, untuk mengindentifikasi masalah dengan melakukan observasi keadaan umum pasien pada saat datang, pengukuran tanda - tanda vital, anamnesa keluhan dan melakukan pemeriksaan fisik. Andersson,Omberg \& Svedlund, (2006) menjelaskan bahwa ketika perawat memutuskan keputusan triase, perawat harus melakukan penilaian terhadap status klinis pasien dengan mengajukan pertanyaan, melihat dan memeriksa. Setelah perawat mengetahui kondisi pasien selanjutnya adalah menentukan tingkat kegawatannya. Peran dan fungsi perawat gawat darurat salah satunya adalah melakukan triase, mengkaji dan menetapkan prioritas dalam spektrum yang lebih luas terhadap kondisi klinis dengan berbagai yang bersifat mendadak mulai dari ancaman nyawa sampai kondisi kritis. Dijelaskan bahwa perawat yang dimaksud adalah mereka yang berkompeten, mengikuti pelatihan tentang kegawatdaruratan. Sistem tingkat kedaruratan triase mempunyai arti yang penting karena triase merupakan suatu proses mengkomunikasikan kondisi kegawatdaruratan pasien di IGD. Jika data hasil pengkajian triase dikumpulkan secara akurat dan konsisten, maka perawat IGD dapat menggunakan keterangan tersebut untuk menilai dan menganalisis, serta menentukan suatu kebijakan, 
seperti berapa lama pasien dirawat di ruang IGD, berapa hari pasien harus dirawat di rumah sakit jika pasien diharuskan rawat inap dan sebagainya (ENA,2005).

\section{PENUTUP}

Pengambilan keputusan mengenai triase yang dilakukan oleh perawat triase sangat ditentukan oleh tingkat pengetahuan triase. Pengetahuan dan pedoman mengenai triase menjadi pilar yang utama untuk mendukung pelaksanaan triase di ruang gawat darurat. Sangat dibutuhkan penyebaran informasi, sosialisasi, seminar ataupun pelatihan triase kepada perawat gawat darurat untuk menjamin pelaksanaan triase berfokus pada keselamatan pasien. Saat pelaksanaan triase sudah sesuai dengan standar pedoman pelaksanaan triase, kualitas layanan gawat darurat menjadi lebih optimal, mengurangi memumpukkan pasien pada salah satu skala triase dan membuat waktu tunggu pasien efektif sesuai dengan kondisi klinisnya. Dari hasil ini diharapkan diperoleh gambaran bagi perawat, bahwa begitu besarnya pengaruh pengetahuan dalam penanganan penderita gawat darurat. Sehingga termotivasi untuk melakukan tindakan yang lebih baik dengan cara peningkatan pengetahuan dengan mengikuti diskusi / seminar, atau melanjutkan pendidikan yang formal. Dan juga diharapkan dari hasil kajian ini, dapat memberikan masukan bagi institusi rumah sakit dalam pengembangan program kesehatan dan pihak rumah sakit diharapkan dapat menyelengggarakan pelatihan - pelatihan bagi tenaga medis khususnya perawat dalam penilaian triase. Sekaligus berguna untuk meningkatkan kualitas Rumah sakit.

\section{DAFTAR PUSTAKA}

Apriani. (2019). Ketepatan Penilaian Triase Dan Pendidikan Petugas Kesehatan Dengan Tingkat Keberhasilan Penanganan Asma. Jurnal Ilmiah Multi Science Kesehatan. Volume 11, Desember 2019

Fadli, Sastria, A.Usman, E. (2017). Pengetahuan Dan Pengalaman Perawat Dalam Penilaian Triage Di Instalasi Gawat Darurat. Jurnal Ilmiah Kesehatan Pencerah. Volume 6 Nomor 1

Gustia, Mila. Manurung, Melva. (2018). Hubungan Ketepatan Penilaian Triase Dengan Tingkat Keberhasilan Penanganan Pasien Cedera Kepala Di IGD RSU HKBP Balige Kabupaten Toba Samosir. Jurnal JUMANTIK Vol.3 No.2 
Khairina, I. Malini, H. Huriani, E. (2018). Faktor - Faktor Yang Berhubungan Dengan Pengambilan Keputusan Perawat Dalam Ketepatan Triase Di Kota Padang. Indonesian Journal for Health Sciences. Vol.02, No.01, Maret 2018

Khairina, I. Malini, H. Huriani, E.. (2020). Pengetahuan Dan Keterampilan Perawat Dalam Pengambilan Keputusan Klinis Triase. Jurnal Link.16 (1), 2020,1-5

Kundiman, V. Kumaat, L. Kiling, M. (2019). Hubungan Kondisi Overcrowded Dengan Ketepatan Pelaksanaan Triase Di Instalasi Gawat Darurat RSU GMIM Pancaran Kasih Manado. e-journal Keperawatan (e-Kp). Volume 7,Nomor 1

Laoh, J. M., \& Rako, K. (2014). Gambaran Pengetahuan Perawat Pelaksana Dalam Penanganan Pasien Gawat Darurat Di Ruangan IGD Blu RSUP. Prof. Dr. R. D Kandou Manado, 3(September), 43-51.

Ratna Sari, D. Sutanta. (2017). Sikap Dan Pengetahuan Perawat Berhubungan Dengan Pelaksanaan Triage. Jurnal Kebidanan. Vol.IX, No. 02

Rizki, T., \& Handayani, T. N. (2018). Pengetahuan Dan Keterampilan Perawat Dalam Melaksanakan Triage, IV(1), 26-32.

Simamora, R. H. (2005). Hubungan Persepsi Perawat Pelaksana Terhadap Penerapan Fungsi Pengorganisasian Yang Dilakukan Oleh Kepala Ruangan Dengan Kinerjanya Diruang Rawat Inap RSUD Koja Jakarta Utara (Doctoral dissertation, Tesis FIK UI, Tidak dipublikasikan).

Simamora, R. H. (2019). Menjadi perawat yang: CIH’HUY. Surakarta: Kekata Publisher.

Sudrajat, A., Haeriyanto, S., \& Iriana, P. (2014). Hubungan Pengetahuan dan Pengalaman Perawat Dengan Keteranpilan Triase Pasien Di IGD RSCM, 2 no. 3, 118-129 